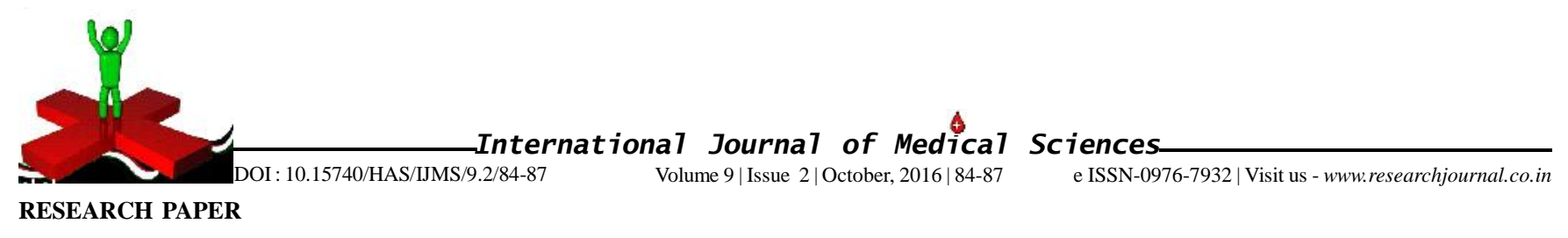

\title{
Acacia senegal Possesses in vitro Cytotoxicity Against Human Cancer Cells
}

\section{VIKAS SHARMA}

Correspondence to :

VIKAS SHARMA

Division of Biochemistry, Faculty of Basic Science, Sher-e-Kashmir University of Agricultural Sciences and Technology (J.), Chatha, JAMMU (J\&K) INDIA

\section{KEY WORDS :}

Acacia senegal, Human cancer cells, Neuroblastoma

\begin{abstract}
In vitro assay for cytotoxic activity of Acacia senegal has been carried out against four human cancer cell lines from four different tissues via aqueous extract at the concentration of 10,30 and $100 \mu \mathrm{g} / \mathrm{ml}$ using Sulphorhodamine blue (SRB) assay. Results revealed that fruit and seed part of the plant showed remarkable in vitro cytotoxic potential against three human cancer cells of cervical ( $\mathrm{SiHa}$ ), neuroblastoma (IMR-32) and lung (A-549) origin at the concentration of 30 and $100 \mu \mathrm{g} / \mathrm{ml}$. Based on in vitro data, it is suggested that further in vivo studies as well as identification of effective components could be useful in designing new anti-cancer therapeutic agents from this particular plant.
\end{abstract}

How to cite this paper : Sharma, Vikas (2016). Acacia senegal Possesses in vitro Cytotoxicity Against Human Cancer Cells. Internat. J. Med. Sci., 9(2) : 84-87, DOI : 10.15740/HAS/IJMS/9.2/84-87. 